\title{
Assessment of Genetic Variability, Heritability and Genetic Advance for Grain Yield and Its Contributing Traits in Wheat (Triticum aestivum)
}

\author{
Anu $^{1 *}$, Vikram Singh ${ }^{1}$, Shikha Yashveer ${ }^{2}$, Ram Niwas $^{3}$, Pooja Malik ${ }^{1}$, Arpit ${ }^{1}$, \\ Susmita Dey ${ }^{1}$ and Umang Ahlawat ${ }^{4}$
}

${ }^{1}$ Department of Genetics \& Plant Breeding, Chaudhary Charan Singh Haryana Agricultural University, Hisar, Haryana (125004), India

${ }^{2}$ Department of Molecular Biology, Biotechnology \& Bioinformatics, Chaudhary Charan

Singh Haryana Agricultural University, Hisar, Haryana (125004), India

${ }^{3}$ Computer Section, Chaudhary Charan Singh Haryana Agricultural University, Hisar, Haryana (125004), India

${ }^{4}$ Department of Microbiology, Chaudhary Charan Singh Haryana Agricultural University, Hisar, Haryana (125004), India

*Corresponding author

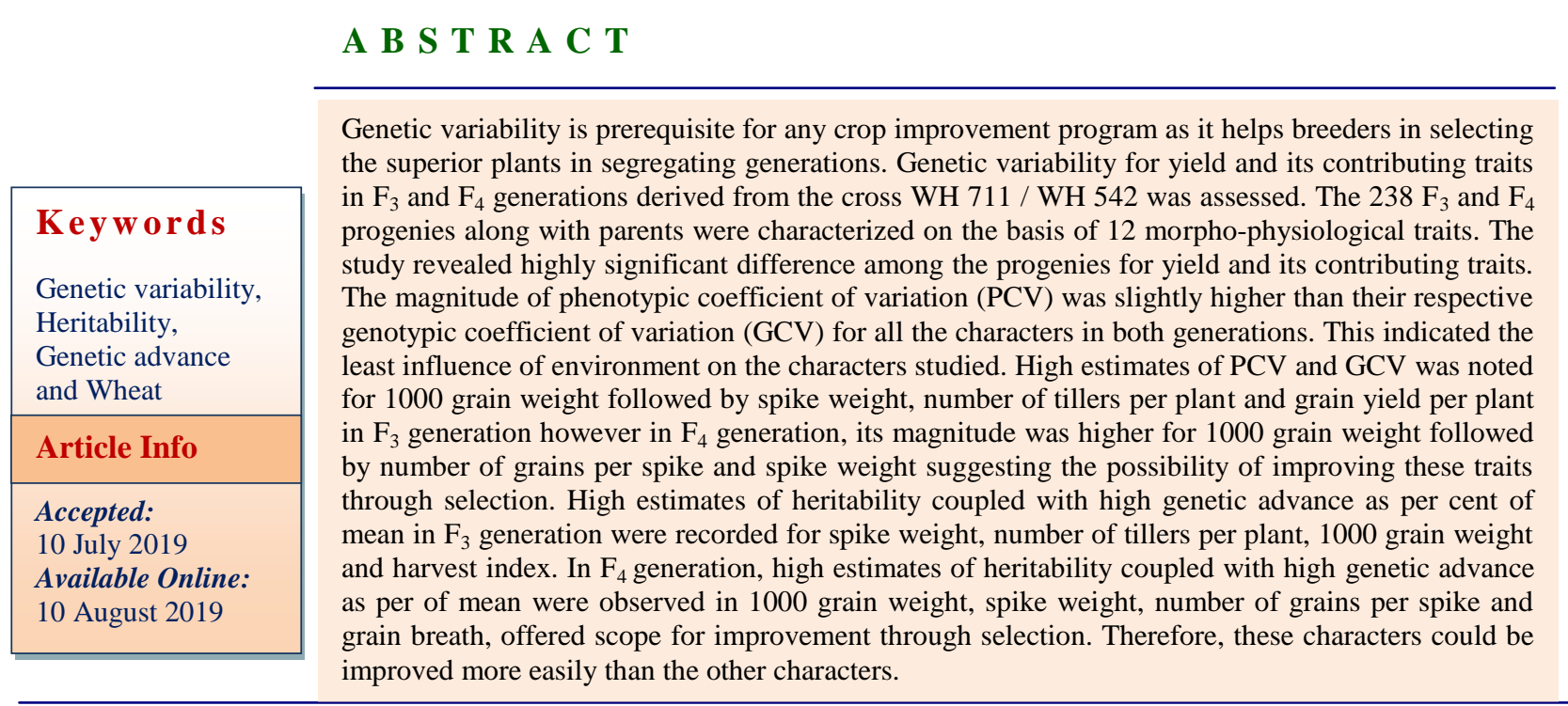

\section{Introduction}

Wheat comprises of many species from the genera Triticum and Aegilops. It belongs to the family Poaceae which is the largest family with in the monocotyledonous plants. In India bread wheat (T. aestivum) is being cultivated roughly on $95 \%$ of the total wheat crop area. The remaining $4 \%$ is tetraploid durum wheat (T. durum), which is used for making pasta and other semolina products and $1 \%$ area is under $T$. dicoccum. Wheat is one of the most 
important cereal crops cultivated worldwide which contributes substantially to human diet and food security. In the developing world, increasing wheat yield potential is the primary aim for food security concern (Duveiller et al., 2007). Wheat was grown on 220.06 million hectares throughout the world with a production of 763.18 million tons of grain and productivity of 3.47 metric tons per hectare during the year 2017-18 (Anonymous, 2019). India is the second largest producer of wheat in the world with area, production and productivity of 30.79 million hectares, 98.51 million tons and 3.20, metric tons per hectare respectively during 2017-18 (Anonymous, 2019)

In view of ever increasing population and demand, there is an imperative need of 40 $60 \%$ increase in wheat production in coming 40 years (Goutam et al., 2015). However, biotic and abiotic stresses are major hurdles for attaining the goal. Among the fungal diseases in wheat, yellow rust is the most devastating disease especially in areas with cool and moist environments. Yellow rust infects cereal crops and grasses from early growth stages to maturity of the plant causing severe yield losses (50-100\%) (Afzal et al., 2007). In order to sustain wheat production, continuous efforts are to be made to develop high yielding and disease resistant wheat genotypes. Accomplishing this goal, the systematic attempts for wheat improvements are needed through manipulation of various yield components (Hussein et al., 2007).

Grain yield being a complex trait is highly influenced by many genetic factors and environmental fluctuations. Heritability and genetic advance are important parameters which help plant breeder in determining the characters for which selection will be done. Keeping in view the above perspectives, the present investigation was taken up to find out genetic variability, heritability and genetic advance for grain yield and component traits in wheat.

\section{Materials and Methods}

The present study was carried out on $238 \mathrm{~F}_{3}$ \& $\mathrm{F}_{4}$ progenies of wheat generated from the cross WH 711 / WH 542, in which WH 542 is yellow rust resistant parent whereas WH 711 is a rust susceptible parent. The crop was grown in research area of Wheat and Barley Section, Department of Genetics and Plant Breeding, CCS Haryana Agricultural University, Hisar, during the Rabi season of 2014-15 and 2015-16. All $F_{3} \& F_{4}$ progenies were grown in the single row of two meter length, keeping row to row distance of 20.5 $\mathrm{cm}$. All the recommended package of practice was followed to raise the crop. At maturity five plants from each progeny were selected randomly to collect data on grain yield and its component traits viz.,plant height $(\mathrm{cm})$, number of tillers per plant, spike length $(\mathrm{cm})$, spike weight (g), number of spikelets per spike, grain breadth $(\mathrm{mm})$, grain length $(\mathrm{mm})$, number of grains per plant, 1000 grain weight $(\mathrm{g})$, grain yield per plant (g), biological yield per plant $(\mathrm{g})$ and harvest index (\%).The data were analyzed for variability parameters like genotypic coefficient of variation (GCV), phenotypic coefficient of variation (PCV), broad sense heritability $\left(h^{2} b s\right)$ and genetic advance as per cent of mean (GAM) using indostat-software.

\section{Results and Discussion}

For the adoption of suitable breeding programmes, the assessment of heritable and non-heritable components in the total variability observed is indispensable. The heritable component can be assessed by studying phenotypic coefficient of variation (PCV), genotypic coefficient of variation $(\mathrm{GCV})$, heritability and predicted genetic advance. 
The estimates of mean, range, phenotypic coefficient of variation (PCV), genotypic coefficient of variation (GCV), heritability (broad sense, in \%) and genetic advance per cent of mean (GAM) are presented in Table 1. The mean value for grain yield per plant varied from $10.20-28.40 \mathrm{~g}$ with an average of $17.29 \mathrm{~g}$ in $\mathrm{F}_{3}$ generations while in $\mathrm{F}_{4}$ it ranged from $11.46-32.18 \mathrm{~g}$ with an average of $21.82 \mathrm{~g}$. A marginal increase in mean value was observed for most of the characters from $\mathrm{F}_{3}$ to $\mathrm{F}_{4}$ generation as shown in Table 1 . The performance of segregants from one year to next year is variable and unpredictable which indicates that yearly change in environment and segregation has effect on the performance of progenies (Brown et al., 2014). The range for under the study was higher in $\mathrm{F}_{4}$ generation as compared to $F_{3}$ generation for most of the characters. Superiority of $F_{3}$ and $F_{4}$ segregants are due to additive $\mathrm{x}$ additive and dominant $\mathrm{x}$ dominant interactions while no such types of interactions are present in later generations in case of self-pollinated crops (Mather and Jinks, 1971).

\section{Phenotypic and genotypic coefficient of variation}

The magnitude of phenotypic coefficient of variation was slightly higher than their respective genotypic coefficient of variation for all the characters in both the generations. This indicated the least influence of environment on the characters studied. These results are in accordance with the results of Kaushik et al., (2013) and Shankarrao et al., (2010).

High estimates of PCV and GCV was observed for 1000 grain weight $(15.63,13.76)$ followed by spike weight $(13.85,13.11)$, number of tillers per plant $(13.00,12.29)$ and grain yield per plant $(12.95,10.44)$ in $F_{3}$ generation however in $\mathrm{F}_{4}$ generation, GCV and PCV its magnitude was higher for 1000 grain weight $(18.43,17.87)$ followed by number of grains per spike $(15.46,13.58)$ and spike weight $(15.38,14.70)$. Rest of the traits had moderate to low $(<10 \%)$ PCV and GCV. Similar findings were also reported by Ali et al., (2008) and Kalimullah et al., (2012) for grain yield per plant; Kumar et al., (2012a) for number of tillers per plant and biological yield per plant, Choudhary et al., (2015) for number of effective tillers per plant and Fikre et al., (2015) for grain yield per plant, 1000 grain weight and number of tillers per plant in bread wheat. The value of PCV for 1000 grain weight, number of grains per spike, spike weight, grain breadth, plant height and number of spikelets per spike in $\mathrm{F}_{4}$ generation exceeded the values in $F_{3}$ generation (Table 1). Since the PCV is the combination of additive and environmental variance, the increase in PCV value in $\mathrm{F}_{4}$ condition may be due to environmental factors, not due to additive or dominant gene action only, because in practical there is tendency in decrease in variability in advance generations due to increase in homozygosity.

Thus, the traits with high GCV are to be considered during selection. High to moderate GCV was observed for 1000 grain weight, spike weight, number of grains per spike and number of tillers per plant in both generations. Such results are in concurrence with the result of Yadawad et al., (2015) and Arya et al., (2017) for grain yield per plant and Rathwa $e t$ al., (2018) for number of tillers plant per plant, grain yield per plant and harvest index. Jan and Kashyap (2013) also reported high $\mathrm{GCV}$ for number of tillers per plant and grain yield per plant.

\section{Heritability and genetic advance}

Heritability (broad sense) estimates was high (>70\%) for spike length, spike weight, 1000 grain weight, grain breath and grain length in both generations. 
Table.1 Mean, range, phenotypic and genotypic coefficients of variations, heritability and genetic advance for different traits in $\mathrm{F}_{3}$ \& $\mathrm{F}_{4}$ progenies derived from cross WH711 / WH 542

\begin{tabular}{|c|c|c|c|c|c|c|c|c|c|}
\hline \multicolumn{2}{|l|}{ Traits } & \multicolumn{4}{|c|}{ Phenotypic parameters } & \multicolumn{4}{|c|}{ Genetic parameters } \\
\hline Plant height (cm) & $\mathrm{F}_{3}$ & \begin{tabular}{|l|} 
WH \\
542 \\
90.2
\end{tabular} & $\begin{array}{l}\text { WH } \\
711 \\
87.6\end{array}$ & $\begin{array}{c}\text { Mean } \pm \text { SE }(m) \\
88.90 \pm 6.33\end{array}$ & $\begin{array}{c}\text { Range } \\
75.20-106.40\end{array}$ & $\begin{array}{l}\text { PCV } \\
(\%) \\
6.69\end{array}$ & $\begin{array}{l}\text { GCV } \\
(\%) \\
2.24\end{array}$ & $\begin{array}{c}\mathrm{h}^{2}(\mathrm{bs}) \\
\% \\
11.2\end{array}$ & $\begin{array}{r}\text { GAM } \\
1.55\end{array}$ \\
\hline & $\mathrm{F}_{4}$ & 89.26 & 82 & $8355+536$ & $72.00-102.00$ & 744 & 3.27 & 257 & 3.94 \\
\hline \multirow{2}{*}{$\begin{array}{l}\text { Number of tillers } \\
\text { per plant }\end{array}$} & $\mathrm{F}_{3}$ & 14.2 & 15.4 & $12.10 \pm 0.33$ & $7.20-17.60$ & 13 & 12.29 & 89.4 & 23.94 \\
\hline & $\mathrm{F}_{4}$ & 14.4 & 15.6 & $13.42 \pm 0.64$ & $7.00-18.80$ & 11.71 & 9.14 & 60.9 & 14.69 \\
\hline \multirow[t]{2}{*}{ Spike length $(\mathrm{cm})$} & $\mathrm{F}_{3}$ & 11 & 10 & $10.61 \pm 0.48$ & $8.00-12.00$ & 8.93 & 7.73 & 74.8 & 13.77 \\
\hline & $\mathrm{F}_{4}$ & 12 & 11 & $11.60 \pm 0.48$ & $9.00-13.00$ & 8.28 & 6.94 & 70.3 & 11.99 \\
\hline \multirow{2}{*}{$\begin{array}{l}\text { Number of } \\
\text { spikelets per spike }\end{array}$} & $\mathrm{F}_{3}$ & 21 & 20 & $20.48 \pm 0.89$ & $17.00-23.00$ & 5.46 & 3.31 & 36.8 & 4.14 \\
\hline & $\mathrm{F}_{4}$ & 21.8 & 20.2 & $20.72 \pm 0.90$ & $19.00-23.00$ & 5.72 & 3.73 & 42.6 & 5.01 \\
\hline \multirow[t]{2}{*}{ Spike weight (g) } & $\mathrm{F}_{3}$ & 3.04 & 2.97 & $2.96 \pm 0.13$ & $1.91-3.80$ & 13.85 & 13.11 & 89.5 & 25.54 \\
\hline & $\mathrm{F}_{4}$ & 3.12 & 3.05 & $3.84 \pm 0.17$ & $2.04-4.04$ & 15.38 & 14.7 & 91.3 & 28.94 \\
\hline \multirow{2}{*}{$\begin{array}{l}\text { Number of grains } \\
\text { per spike }\end{array}$} & $\mathrm{F}_{3}$ & 62 & 55 & $50.22 \pm 3.56$ & $35.00-67.00$ & 12.79 & 10.66 & 69.5 & 18.3 \\
\hline & $\mathrm{F}_{4}$ & 64 & 57 & $56.16 \pm 4.25$ & $34.00-75.00$ & 15.46 & 13.58 & 77.1 & 24.57 \\
\hline \multirow[t]{2}{*}{ Grain length (mm) } & $\mathrm{F}_{3}$ & 5.74 & 5.6 & $5.94 \pm 0.13$ & $4.42-6.90$ & 6.14 & 5.76 & 87.9 & 11.11 \\
\hline & $\mathrm{F}_{4}$ & 5.98 & 5.84 & $6.05 \pm 0.12$ & $5.36-6.62$ & 4.92 & 4.54 & 84.8 & 8.61 \\
\hline \multirow{2}{*}{$\begin{array}{l}\text { Grain breadth } \\
(\mathbf{m m})\end{array}$} & $\mathrm{F}_{3}$ & 3.26 & 3.12 & $3.31 \pm 0.09$ & $2.15-4.06$ & 7.95 & 7.53 & 89.6 & 14.69 \\
\hline & $\mathrm{F}_{4}$ & 3.2 & 3.13 & $3.36 \pm 0.07$ & $2.69-3.90$ & 8.28 & 8.03 & 94.1 & 16.04 \\
\hline \multirow{2}{*}{$\begin{array}{l}1000 \text { grain weight } \\
\text { (g) }\end{array}$} & $\mathrm{F}_{3}$ & 40.84 & 40.6 & $37.90 \pm 0.28$ & $25.30-50.10$ & 15.63 & 13.76 & 77.6 & 24.96 \\
\hline & $\mathrm{F}_{4}$ & 40.22 & 40.63 & $33.0 \pm 0.15$ & $26.70-52.90$ & 18.43 & 17.87 & 94 & 35.68 \\
\hline \multirow{2}{*}{$\begin{array}{l}\text { Grain yield per } \\
\text { plant }(\mathrm{g})\end{array}$} & $\mathrm{F}_{3}$ & 22.28 & 20.84 & $17.29 \pm 2.71$ & $10.20-28.40$ & 12.95 & 10.44 & 65 & 17.34 \\
\hline & $\mathrm{F}_{4}$ & 22.67 & 20.49 & $21.82 \pm 2.77$ & $11.46-32.18$ & 9.34 & 5.77 & 38.1 & 7.34 \\
\hline \multirow{2}{*}{$\begin{array}{l}\text { Biological yield per } \\
\text { plant }(\mathrm{g})\end{array}$} & $\mathrm{F}_{3}$ & 53.82 & 51.1 & $55.76 \pm 6.32$ & $25.94-65.80$ & 10.52 & 7.97 & 57.5 & 12.45 \\
\hline & $\mathrm{F}_{4}$ & 52.92 & 51.26 & $67.68 \pm 6.51$ & $28.77-68.61$ & 7.79 & 3.55 & 20.7 & 3.32 \\
\hline \multirow[t]{2}{*}{ Harvest index (\%) } & $\mathrm{F}_{3}$ & 41.39 & 40.78 & $38.51 \pm 1.72$ & $27.10-45.82$ & 10.07 & 9.04 & 80.6 & 16.71 \\
\hline & $\mathrm{F}_{4}$ & 42.84 & 39.97 & $40.61 \pm 2.97$ & $32.42-45.88$ & 6.09 & 4.09 & 45.2 & 5.67 \\
\hline
\end{tabular}

Heritability estimate is useful in deciding the characters to be considered while making selection, but selection based on heritability alone may limit the progress, as it is prone for changes with change in environment, material etc. (Johanson et al., 1955). Among all the studied character, high estimates of heritability coupled with high genetic advance as per cent of mean in $\mathrm{F}_{3}$ generation was recorded for spike weight $(89.5,25.54)$, number of tillers per plant (89.4, 23.94), 1000 grain weight $(77.60,24.96)$ and harvest index (80.60, 16.71), respectively. In $\mathrm{F}_{4}$ generation, high estimates of heritability coupled with high genetic advance as per of mean was observed in 1000 grain weight $(94.00,35.68)$, spike weight $(91.3,28.94)$, number of grains per spike $(77.10,24.57)$ and grain breath (94.10, 16.04) respectively. These results are in agreement with the finding of Choudhary et al., (2015) who reported similar results for number of tillers per plant.

Moderate estimates of heritability coupled with moderate genetic advance as per cent of mean was recorded for spike length and grain length in both $\mathrm{F}_{3} \& \mathrm{~F}_{4}$ generation, however in $\mathrm{F}_{3}$ generation it was recorded for number of grains per spike, grain breath, grain yield per plant and biological yield per plant. Similar findings were also reported by Shankarrao et $a l$. , (2010) for number of grains per spike and 
Rathwa et al., (2018) for number of tillers per plant followed by grain yield per plant, harvest index and grain weight per spike. Heritability values may vary from generation to generation. There is no consistent tendency of increase or decrease in heritability from one generation to next generation.

It can be concluded from the above mentioned findings and details that the progenies used in the study exhibited considerable variability for various traits under study in both the generations and opportunities of the genetic gain through selection or hybridization. High estimates of PCV and GCV was noted for 1000 grain weight, spike weight, number of tillers per plant and number of grains per spike suggesting the possibility of improving these traits through selection. High heritability coupled with high genetic advance in per cent of mean was recorded for spike weight and 1000 grain weight, offered scope for improvement through selection. Therefore, these characters could be improved more easily than the other characters.

\section{References}

Afzal, S.N., Haque, M., Ahmedani, M., Bashir, S., Rattu, A. 2007. Assessment of yield losses caused by Puccinia striiformis triggering stripe rust in the most common wheat varieties. Pak. J. Bot., 39: 2127- 2134.

Anonymous. 2018. Progress Report of the All India Co-ordinated Wheat and Barley Improvement Project. Crop Improvm. 01. ICAR-Indian institute of Wheat and Barley Research, Karnal, India.

Anonymous. 2019. Progress Report of the All India Co-ordinated Wheat and Barley Improvement Project. Crop Improvm. 01. ICAR-Indian institute of Wheat and Barley Research, Karnal, India.

Arya, V.K., Singh, V., Kumar, L., Kumar, R., Kumar, P. and Chand, P. 2017. Genetic variability and diversity analysis for yield and its components in wheat (Triticum aestivum L.) Indian Journal of Agricultural Research, 51(2): 128134.

Bhushan, B., Gaurav, S.S., Kumar, R., Rishi Pal, Panday, M., Kumar, A., Bharti, S., Nagar, S.S., Rahul, V.P. 2013. Genetic variability, heritability and genetic advance in bread wheat (Triticum aestivum L.). Environment \& Ecology, 31(2): 405- 407.

Brown, J., Caligari, P. and Campos, H. 2014. Plant breeding $2^{\text {nd }}$ edition, John Willey and sons, West Sussex.

Choudhary, R.C., Sharma, N.K., Kumar, R. and Kumar, M. 2015. Genetic variability, heritability and genetic advance in wheat under different normal and heat stressed environments. Electronic Journal of Plant Breeding, 6(4): 1082-1087.

Duveiller, E., Singh, R.P. and Nicol, J.M. 2007. The challenges of maintaining wheat productivity: pests, diseases and potential epidemics. Euphytica, 157: $417-430$.

Fikre, G., Alamerew, S., Tadesse, Z. 2015. Genetic variability studies in bread wheat (Triticum aestivum L.) genotypes at Kulumsa Agricultural Research Center, South East Ethiopia. Journal of Biology, Agriculture and Healthcare, 5(7): 89-98.

Goutam, U., Kukreja, S., Yadav, R., Salaria, N., Thakur, K. and Goyal, A.K. 2015. Recent trends and perspectives of molecular markers against fungal diseases in wheat. Frontiers in microbiology, 6:861.

Hussain, S.S. and Qamar, R. 2007. Wheat genomics: challenges and alternative strategies. Proc. Pakistan Acad. Sci., 44(4): 305-327.

Jan, N. and Kashyap, S.C. 2013.Studies on genetic variability in wheat (Triticum 
aestivum $\mathrm{L}$.) under temperate conditions of Kashmir. Inter. J. Scie. Res., 5: 14421445.

Johnson, H.W., Robinson, H.F. and Comstock, R.E. 1955. Estimates of genetic and environmental variability in soybean. Journal of Agronomy, 47: 314318.

Kalimullah, Khan, S.J., Irfaq, V. and Rahman, H.U. 2012. Genetic variability, correlation and diversity studies in bread wheat (Triticum aestivum L.) germplasm. The Journal of Animal \& Plant Sciences, 22(2): 330-333.

Kaushik, S.K., Tomar, D.S., Dixit, A.K. and Saxena, A.K. 2013. Assessment of wheat varieties in Central India under changed climatic scenario. Wudpecker J. Agric. Res., 2(2): 64-66.

Khan, N. and Naqvi, F.N. 2011. Heritability of morphological traits in bread wheat advanced lines under irrigated and nonirrigated conditions. Asian J. Agri. Sci., 3(3): 215-222.

Mather, K. and Jinks, J.L. 1971. Biometrical genetics, Cornell University Press,
Ithaca. O'Brien L, Baker RJ and Evans LE, 1978. Response to selection for yield in $\mathrm{F}_{3}$ of four wheat crosses. Crop Science, 18:1029-1033.

Rathwa, H.K., Pansuriya, A.G., Patel, J.B. and Jalu, R.K. 2018. Genetic variability, heritability and genetic advance in durum wheat (Triticum durum Desf.). International Journal of Current Microbiology and Applied Sciences, 7(1): 1208-1215.

Shankarrao, B.S., Mukherjee, S., Pal., A.K. \& De, D.K. 2010. Estimation of variability for yield parameters in Bread Wheat (Triticum aestivum L.) grown in Gangetic West Bengal. Electrical Journal of Plant Breeding, 1(4): 764768.

Yadawad, A., Hanichinal, R.R., Naday, H.L., Desai, S.A., Biradar, S. and Naik, V.R. 2015. Genetic variability for yield parameters and rust resistance in $\mathrm{F}_{2}$ population of wheat (Triticum aestivum L.). The Bioscan 10(2): 707-710.

\section{How to cite this article:}

Anu, Vikram Singh, Shikha Yashveer, Ram Niwas, Pooja Malik, Arpit, Susmita Dey and Umang Ahlawat. 2019. Assessment of Genetic Variability, Heritability and Genetic Advance for Grain Yield and Its Contributing Traits in Wheat (Triticum aestivum). Int.J.Curr.Microbiol.App.Sci. 8(08): 1169-1174. doi: https://doi.org/10.20546/ijcmas.2019.808.137 